IZA DP No. 5652

Subject Choice and Earnings of UK Graduates

Arnaud Chevalier

April 2011 


\title{
Subject Choice and Earnings of UK Graduates
}

\author{
Arnaud Chevalier \\ Royal Holloway University of London, \\ Geary Institute (UCD), CEE (LSE) and IZA
}

Discussion Paper No. 5652

April 2011

IZA

P.O. Box 7240

53072 Bonn

Germany

Phone: +49-228-3894-0

Fax: +49-228-3894-180

E-mail: iza@iza.org

\begin{abstract}
Any opinions expressed here are those of the author(s) and not those of IZA. Research published in this series may include views on policy, but the institute itself takes no institutional policy positions.

The Institute for the Study of Labor (IZA) in Bonn is a local and virtual international research center and a place of communication between science, politics and business. IZA is an independent nonprofit organization supported by Deutsche Post Foundation. The center is associated with the University of Bonn and offers a stimulating research environment through its international network, workshops and conferences, data service, project support, research visits and doctoral program. IZA engages in (i) original and internationally competitive research in all fields of labor economics, (ii) development of policy concepts, and (iii) dissemination of research results and concepts to the interested public.
\end{abstract}

IZA Discussion Papers often represent preliminary work and are circulated to encourage discussion. Citation of such a paper should account for its provisional character. A revised version may be available directly from the author. 
IZA Discussion Paper No. 5652

April 2011

\section{ABSTRACT}

\section{Subject Choice and Earnings of UK Graduates ${ }^{*}$}

Using a survey of a cohort of UK graduates, linked to administrative data on higher education participation, this paper investigates the labour market attainment of recent graduates by subject of study. We document a large heterogeneity in the mean wages of graduates from different subjects and a considerably larger one within subject with individuals with the most favourable unobserved characteristics obtaining wages almost twice as large as those with the worst. Moreover, gender differences in wages within subjects are also large. We then simulate a graduate tax to calculate a willingness to pay - in form of tuition fees - to capture these subject wage premia.

JEL Classification: $\quad$ 122, J31

Keywords: graduate earnings, tuition fees

Corresponding author:

Arnaud Chevalier

Department of Economics

Royal Holloway, University of London

Egham, Surrey TW20 0EX

United Kingdom

E-mail: arnaud.chevalier@rhul.ac.uk

\footnotetext{
* This paper was drafted during a placement at the Department for Innovation, Universities and Skills, now the department for Business Innovations and Skills. The views represented in this manuscripts are the author's and do not represent the view of the BIS. Additional work was completed during my stay at TIER, University of Amsterdam which must be thanked for their hospitality. I also want to thank Colm Harmon and one anonymous referee for their dedicated reading and precise comments and also Stijn Broecke, Gauthier Lanot and Tarja Viitanen for commenting on previous versions of this draft. Financial support from the ESRC under their placement scheme is also gratefully acknowledged (RES-173-27-0040).
} 


\section{Introduction}

The markets for higher education in Europe are quite regulated with little freedom for institutions to determine tuition fees, which in general are low and rarely differ by subject. At the same time, the costs of providing programs differ substantially ${ }^{1}$. The unique tuition price thus creates equity problems, especially when students in the costlier programs (receiving the highest subsidies) become graduates earning the most ${ }^{2}$. Indeed the UK white paper on the future of higher education (2003) notes that: "We believe that a revised contribution system should recognise these differences [in average returns] properly, and not ask students who can't expect such good prospects in the labour market to subsidise those that can, through a flat fee” (DfES, 2003, p88). Reforms to create a market for higher education, as in England, potentially allow for price differentiation between subjects. Hence, it is timely to report on the wage differentials by subjects for a recent cohort of UK graduates, to assess a willingness to pay for different subjects.

As demonstrated by Dearden et al. (2008), reforms to the funding of higher education have important redistributional effects which differ by gender. We thus investigate whether there are any gender differences in the subject premiums. Indeed, while the overall gender wage gap is small amongst this cohort of recent graduates, we report large gender differences in earnings within subjects. Moreover, if fees are allowed to differ by subjects, prospective students need information on the mean wages but also on their dispersions. We thus investigate the within subject differences in wages using quantile estimators. The issue of wages dispersion within subject has so far been largely ignored.

\footnotetext{
${ }^{1}$ For example, the Higher Education Funding Council for England grants institutions between £15,788, and £3,947 (in 2008) per student depending on their subject of study.

${ }^{2}$ It could be argued that subsidies should be based on the social returns to the education provided but not on the costs of provision.
} 
Finally, we compute the life time wage profile of graduates and compute the present value of a graduate tax. Assuming that students had perfect forecast on the wage profiles this present value would be equivalent to the maximum willingness to pay for different subject choices. These calculations ignore that student may have different preferences for subject and thus lead to upper bound estimates of the willingness to pay for each subject.

The literature estimating returns to subject has found large variations. Indeed, James et al. (1989) states that in the US wage differentials by major are much larger than across institutions. Previous work for the UK (Bratti et al., 2005, Chevalier et al., 2002, Naylor et al., 2002 or Walker and Zhu, 2005) relates to pre-tuition fee cohorts, where subject choice may have been affected by different parameters. For example, the consumption value of education may play a lower role in subject choice when tuition fees are levied. The general conclusion is that there is a large heterogeneity in wages by subjects with health, science and social sciences (mostly economics, law and business) graduates earning more than humanities, education and arts graduates, the difference reaching about 10\%. Walker and Zhu (2010) calculate internal rate of returns for different subjects using the Labour Force Survey (LFS) and report no to low returns to degrees in art, humanities and languages. A similar subject ranking is found in France, Germany and the U.S. (Machin and Puhani, 2006).

In this paper, we rely on evidence from a cohort who paid up-front tuition fees. The Longitudinal Destination of Leavers of Higher Education (LDLHE) surveyed a sample of graduates from the 2003 cohort representing the universe of British higher education institutions ${ }^{3}$. Information on their current labour market achievements is

\footnotetext{
${ }^{3}$ Naylor et al (2002) uses the USR dataset an administrative survey of all UK graduates, 6 months after graduation. While this represents the universe of graduates it lacks information on earnings and the authors use occupation to infer earnings. This may be problematic if occupations 6 months after
} 
collected by survey in November 2006 three years after graduation. The LDLHE is linked to administrative records of the students which include academic attainment and family background. While the data is an improvement on previous graduate surveys since it can be linked to administrative data, its drawback, as with most other graduate surveys, is that earnings are only observed at one early point in the graduates' career.

Specifically, we estimate subject specific wage differentials, for the full sample and separately by gender. Due to the lack of credible identification variables we make the assumption, as in the literature that subject choice is exogenous ${ }^{4}$. The bias, when this assumption is made may be limited when a rich set of controls is available. Indeed Arcidiacono (2004) concludes that in the U.S., subject choice is driven by individual preferences rather than expected future earnings. Beffy et al (2009) using French data, also find limited evidence that variations in wages along the business cycle affect subject choice. Hence estimates of subject wage premium may not be severely biased even if some unobserved characteristics explain both subject choice and earnings. Additionally, we rely on quantile regressions to estimate these differentials at different points of the residual wage distribution, so as to measure the variation in wages within subject. If prospective students are unsure about their position in the unobserved skill distribution or have a strong risk aversion, they may opt for a subject offering lower mean salaries and lower variance. Finally we use these estimates and data from the LFS to compute the associate life-time wage profiles by subjects - thus assuming that the subject specific wage differentials are constant over time - and compute a graduate tax which has the same parameters as the

leaving university are a poor proxy for lifelong occupation. In the LDLHE data, only 38\% of graduates are in the same occupation (at the two digit level) 6 months and 3 years after graduation.

${ }^{4}$ Bratti and Mancini (2003) estimate jointly the subject choice (four broad categories) and earning equations, however the estimated returns to subject are unstable, often jumping from one year to the next by 10 to 30 percentage points, casting doubts on the identifying strategy. 
loan system currently in place. The tuition fees are then the present value of the streams of incomes associated with this tax.

To preview the results, even after accounting for a large set of covariates, we find a substantial amount of heterogeneity in wages for this cohort of graduates. Medicine and dentistry graduates are clear outliers, earning twice as much as psychology graduates (£39,190 vs $£ 19,290$ ), and there is substantial heterogeneity around the average annual earnings of $£ 23,000$. Interestingly, even excluding medics the gap in mean wages between subjects is around 0.25 log points but the gap within subject (90/10 range) is about 3 times larger. This large variation in wages within subjects has previously been largely ignored but potentially affects subject choice. While the overall gender wage gap, at three percent, is limited there are important wage differentials within subjects. For example, male economists earn $17 \%$ more than female's while female graduates in education earn $22 \%$ more than men. In term of tuition fees, the mean wage premia suggest a range of fees from $£ 1,900$ to $£ 5,300$. However, with large variations in wages within subjects and by gender, it is unclear how subject specific tuition fees could be implemented.

\section{Data}

The LDLHE was conducted in November 2006 amongst a random sample of graduates from the academic year 2002/03. This cohort, which typically started university in September 2000, would have been charged up to $£ 1,100$ per year of studies $^{5}$. The survey is conducted in two stages. First, the universe of all the leavers who were UK domiciled prior to attaining higher education is sampled six months after graduation (75\% response rate). In the second stage, a random sample of 55,900

\footnotetext{
${ }^{5}$ Depending on parental income, about one third of students were eligible for full tuition fee subsidies and another third paid reduced fees. The legislation differ for Scottish students who did not have to pay tuition fees.
} 
of these original respondents is selected to take part in the LDLHE. The data is collected using a mixture of postal, phone and online questionnaires and 24,823 of the selected population participated, giving a response rate of $44 \%$ which is pretty standard for this survey methodology, especially when relying on three years old contact details. Furthermore, Tipping and Taylor (2007) provide evidence in favour of the representativeness of the survey, and we discuss below how the distribution of subject compares in the DHLE and the full population.

The LDLHE has several advantages over previously used datasets. It contains the universe of institutions, precise subject of graduation, several measures of academic achievement pre-university and at university as well as labour market information. It can also be linked to administrative data from the Higher Education Statistical Agency (HESA) so that accurate information on family background and, pre- and university achievements can be included. Additionally we supplement the dataset with measures of the quality of the attended institution. In the previous literature this has mostly been omitted which could have lead to biased estimates of the subject premium if, for example, more prestigious institutions are more likely to teach high wage subjects. We measure institution quality along various dimensions including research (Research Assessment Exercise score), teaching (pupil/teacher ratio, expenditure on students, completion rate) and quality of the student body (average entry score), as in the good University Guide ${ }^{6}$.. We use a principal component approach to reduce this information into a single score. The first component accounts for $71 \%$ of the variation and a higher value of the score indicates greater quality. This strategy leads to a ranking of institutions that appears plausible as the top five institutions in the country, in alphabetical order, are Cambridge University, Imperial

\footnotetext{
${ }^{6}$ The Good University Guide is one of the providers of ranking of universities. Rather than using its ranking, we only use the raw variables which can be obtained from: http://www.thegooduniversityguide.org.uk.
} 
College London, London School of Economics, Oxford University and University College London.

The population of interest is limited to first degree holders, currently observed in employment. We further restrict the sample to individuals aged 18 to 25 on graduation, so as to limit the effect of pre-university labour market experience. This leads to a sample of 9,296 observations (See Table A1 for details on the sample selection). We assess the representativeness of the LDLHE survey by comparing it to HESA data on first degree leavers for the year $2002 / 03^{7}$. The distribution of graduates by subjects is reported for the two sources in Table A2. Broadly, the LDLHE is consistent with the administrative data but there are some discrepancies between the two datasets; the largest being observed for subject allied to medicine and education which originates from differences in the coding of mixed subjects ${ }^{8}$. The final sample only contains full-time workers with valid earning information, which drops the number of observations used in the analysis to 7,735. The subject distribution remains very similar when conditioning on wage non-response.

\section{III: Descriptive statistics}

First we describe two characteristics that correlate with subject choice and earnings: A-level score and institution quality (see Table 1). The HESA data includes the score of the best 3 A-levels (or equivalent) for $90 \%$ of the selected sample ${ }^{9}$. The maximum score is 30. Due to strict selection, graduates from medicine and dentistry

\footnotetext{
${ }^{7}$ The Destination of Leavers Higher Education represents the universe of all UK leavers and is the first step survey in the collection of the LDLHE

${ }^{8}$ For example, $50 \%$ of graduates from mixed subject with no science are in a teaching occupation three years after graduation.

${ }_{9}^{9}$ A-levels are the upper high school national examination. It is externally marked. A, B, C, D and E grades are worth $10,8,6,4$, and 2 points respectively. A-levels are not required to attend higher education, so the missing observations are a mix on non-response and no A-levels. In more recent cohorts the tariff score which takes account of all qualifications has been computed, but this is not available for this cohort. The subjects in which the A-levels were taken is not available.
} 
have the highest average test score at 28. The other subjects with high quality intake are math, economics, law, philosophy and languages with an average A-level score above 22, while graduates in education have the lowest average A-level score at 15.

Subject choice may also be correlated to the characteristics of the institution. For example, experimental sciences are expensive to teach and may be more likely to be taught in more prestigious institutions that also generate earning premium (Chevalier, 2010). The second column in Table 1 reports the mean institution quality by subject. Medicine, economics, mathematics and literature are taught in the highest quality institutions. The difference between high and low quality score subjects such as communication and sport sciences reaches almost two standard deviations, highlighting the potential bias in estimates of subject premium that do not control for institution quality.

The LDLHE reports annual earnings three years after graduation. We recode 36 observations with an unusually high salary - compared to their occupation average earnings - which were due to coding errors (additional zero) and drop 149 individuals who claim to earn less than the national minimum wage (assuming they worked 52 weeks a year). The third column of Table 1 reports the average annual earnings for full-time workers earning less than $£ 60,000$ per year. The description by subjects reveals the large heterogeneity in earnings. Medics are the clear outliers with average earnings of $£ 39,000$. The next best paid subjects have mean earnings around the $£ 25,000$ mark, and include subject allied to medicine, mathematics, engineering, architecture and economics. Subjects with the lowest average earnings are Communication, Linguistic, Creative Arts and Psychology with mean wages between $£ 19,000$ and $£ 20,000$. So even excluding medics, there is a $25 \%$ gap in the mean earnings of graduates between the worst and better paid subjects. 
Figure 1 reports the earnings distribution separately for each subject. There are marked differences in the shape of the earnings distribution by subjects. For example, education (and mixed no science), and subject allied to medicine are characterised by narrow distributions since a large fraction of graduates in these subjects become teachers and nurses respectively - occupations mostly found in the public sector that have salaries determined on a national pay scale. Most distributions are uni-modal with the mode around $£ 20,000$; the exceptions are medicine, economics, Finance and Accounting which have a much flatter profile than other subjects.

\section{Empirical strategy}

The descriptive statistics have highlighted that earnings differ by subject. However, since the characteristics of students largely vary by subject we control for these confounding factors in a Mincer log earning specification:

$$
\ln Y=\beta_{0}+\sum_{j} \gamma_{j} S_{j}+\beta_{1} X_{1}+\beta_{2} X_{2}+\beta_{3} G+\varepsilon
$$

where $\ln Y$ is the log annual wage, $S_{j}$ is a dummy variable indicating graduation from subject $j$, so that $\gamma_{j}$ is the estimated mean wage differential for subject $j$ graduates compared to physical sciences graduates. $X_{1}$ and $X_{2}$ are sets of controls for pre- and post- university characteristics respectively. $X_{1}$ varies with specification but in the most extensive model includes ethnicity, age, disability status, parental social class, fee status, type of school attended and A-level score. $X_{2}$ includes institution characteristics such as class of degree and graduating institution quality (or an institution fixed effect), but also labour market experience and job characteristics, which may be correlated with subject $j$ and thus be considered endogenous. $G$ is a dummy variable defining gender and $\varepsilon$ is a random component assumed normally distributed capturing all other factors determining earnings. Since the error term may 
be correlated between individuals from the same institutions the standard errors are clustered at the institution level.

This model is first estimated by Ordinary Least Square (OLS). The estimates are the mean effects of subject of graduation on earnings, after controlling for confounding factors. An extension to this model, includes a set of interaction terms between gender $(G)$ and subjects $\left(S_{j}\right)$. However these models only capture mean differences and fail to capture the heterogeneity in wages within subject. So (1) is also estimated by quantile regression which estimates the subject specific wage premiums at various quantile of the conditional wage distribution (Koenker and Bassett, 1978). The conditional quantiles can be interpreted as individual nonobservable characteristics. The quantile regression model can be written as:

$$
\ln Y=\beta_{\theta 0}+\sum_{j} \gamma_{\theta j} S_{j}+\beta_{\theta 1} X_{1}+\beta_{\theta 2} X_{2}+\beta_{\theta 3} G+\varepsilon_{\theta}
$$

which is estimated at the $\theta^{\text {th }}$ conditional quantile of $\ln Y$. The advantage of quantile regressions is that the effect of a given covariate is not assumed to be fixed across the distribution, i.e. in our specific application the subject wage premium may vary at different points of the income distribution. As such this analysis would lessen the criticism that some unobserved characteristics that influence earnings and choice of degree subject may bias the OLS estimates.

\section{Between subject results}

a- overall between subject wage premiums

OLS results are reported in Table 2. The first column report the raw wage differentials compared to physical science graduates. In specification (2) we control for local labour market as some subjects may be associated with specific locations. For example, graduates from Agricultural studies are more likely to live in rural areas 
and would then be expected to have lower wages all else considered. On the other hand, location may be considered endogeneous if higher earners can afford to live in more desirable part of the country. To limit this potential endogeneity, we use employer's - not own location - and only a two digit postcode defining 126 labour markets. Comparing results in Column (1) and (2) location indeed matters, the wage premiums for some subjects changing by as much as $50 \%$ and the $\mathrm{R}^{2}$ doubling, but no clear pattern emerges.

Medics earn about $60 \%$ more than physics students. Another three subjects are associated with earning premium over physics that are greater than $10 \%$ : subjects allied to medicine, architecture and engineering. Three subjects have substantial lower earnings compared to a physics degree; linguistic, communication and creative art graduates' pay is less than $90 \%$ of physics graduates' pay. Medics are clear outliers, but excluding them, the log wage range is still a substantial 0.28 log points between the best and worst paid subject.

In column (3) we control for personal characteristics: gender, age, ethnicity and parental social class. Since there is little variation in these characteristics by subjects, with the exception of gender, the estimated coefficients remain relatively stable. Adding secondary education achievements (Column (4)) reduces the estimated coefficients since there is a positive correlation between A-level score and wages. Note however, that after accounting for A-level score, education becomes one of the best paid subjects with a premium over physics reaching $9 \%$, since these graduates, despite a low A-level score average enjoy relatively high salary early on in their career. In Column (5) we add more personal characteristics which are approximating the financial constraints of the students: fee status, accommodation type when studying, as well as type of secondary school attended and disability status. These 
have little effect on the subject differentials. After accounting for this extended set of individual characteristics the gap between the best paid and worst paid subject, excluding medicine, is still 0.25 log points, similar to the raw gap. Graduates from subject allied to medicine enjoy the highest mean earnings while those from linguistics and classics have the lowest.

We now control for institutional quality by adding a set of dummies for the quality quartile. The impact on the estimates is small and the direction unclear with non-science subjects generally gaining. In Column (7) we instead includes institution fixed effects to assess whether the small impact made by the inclusion of the quality measure was due to the lack of relevance of institution characteristics or a problem with the proxy used. Again the direction of the changes, when comparing to specification (5) is unclear but for some subjects the gains are substantial. For example, the average wage for psychology graduate is 7.4 log points lower than for physics graduates when omitting institution factors but only 5.4 when including them. So analysis that do not account for institution, either by accounting for some measure of quality or with a fixed effect model, are potentially biased. In this extensive specification the earning gap between subjects is still 0.26 log points, excluding medicine.

Final grade is commonly included in wage regressions of graduates but is potentially endogenous if subjects are not graded to the same standards. While highly significant itself, final grades has an effect on the estimated premium for only a handful of subjects: Architecture, Language, Finance and Psychology. Thus while there are some differences in grading between subjects they do not explain much of the subject gap. Model (9) adds a full set of job and early career characteristics such as tenure, contract type, employer's size, number of jobs and number of months of 
unemployment since graduation, current occupation and highest qualification. These variables are not independent of subject choice and these estimates are thus presented only for completeness. Their inclusion largely reduces the premium for most subjects since part of the subject differential originates from occupational choice. Finally, to try to capture the quality of the job-match, model (10) adds a set of dummies on the reason to accept the current job. These variables depresses the wage differential, especially for medicine, subject allied to medicine, architecture and education, thus the higher earnings from graduates from these subjects may reflect partly some compensating differentials. The larger drops in the wage premium are for health related and education subjects which typically lead to careers in the regulated pay sector. In our favoured models (6), (7) and (8), there are still substantial differences in wages by subject reaching 0.26 log points between subjects allied to medicine and linguistic graduates.

b- gender specific effects

We have so far failed to account for potential gender effects in the subject specific wages. In Table 3, we thus present results, using specification (6) separately by gender ${ }^{10}$. As well as the coefficients of the log wage equation, we report for each subject the predicted wage for an average individual. There are large differences in predicted wages by gender; in particular for graduates from education (mixed subjects without science) and economics where the gaps reach 20 percentage points. Results from a pooled regression interacting subject with gender largely confirm these results but with more precision. The estimated interactions are reported in column (3) of Table 3 and represent the subject specific premiums for men over women assuming everything else constant. Male graduates from the following subjects have

\footnotetext{
${ }^{10}$ Note that early on in their career, there is no difference in labour force participation by gender, so we do not control for participation.
} 
significantly higher earnings than female: Economics $(+0.17)$, law $(+0.12)$, IT $(+0.09)$, subjects allied to medicine $(+0.08)$, while female graduates earn significantly more than male in the following: Education $(+0.22)$, Mixed subjects without science (+0.21), Linguistic (+0.14), History and Philosophy $(+0.09)$ and Mixed subjects with a science $(+0.09)$. While early on in the career of these graduates the overall gender gap at $3 \%$ is small there is a large variation in earnings by gender within subjects. Moreover we replicate the exercise using specification (10) above which includes amongst others occupation and reasons for choosing current job. The gender wage differentials are then reduced but not eliminated, they thus are not solely due to gender differences in occupational choice.

c- Within subject results

When choosing a subject, prospective students have imperfect measures of their position in the ability distribution (Chevalier et al. 2009) and may thus also consider the wage dispersion within subject. We thus re-estimate the log wage equations at nine different quantiles of the earnings distribution controlling for pre-university characteristics and institution quality, as in specification (6) of Table 2. In Table 4, we report the estimated wage differentials at each quantile compare to a physics graduate. The variations in the subject premiums depend on unobserved ability. For example a classic graduate in the $3^{\text {rd }}$ quantile can expect a 0.01 log point lower wage than a physics graduate but at the $9^{\text {th }}$ quantile, the difference reaches 0.19 log point. There is no clear pattern in the earning differentials compare to physics through the quantiles, with about half the subjects showing decreasing differentials through the quantile and the rest showing no clear trend.

Figure 2 presents the predicted log wages at different quantiles for a subset of subjects. The predicted wages are generally increasing in quantile. At each quantile, 
medical graduates earn more than other students, but medics with the worst set of unobservable earn less than graduates from low-pay subject with non-observable characteristics in the top three quantiles. For example a graduate from psychology at the $90^{\text {th }}$ quantile has a predicted ln wage of 10.18 , higher than the earnings of a medic at the $10^{\text {th }}$ quantile (10.09). The ranking of other subjects varies by quantile but some pattern emerges. Amongst the subjects reported in Figure 2, arts, psychology and biology are always the lowest earning subjects at all quantiles. Finance and Law have the steepest profiles. At lower quantiles education offers relatively high wages. This is consistent with education professionals being rewarded on a pay scale, i.e. independently of the graduate's quality, while finance and law professionals are largely rewarded according to their own performance. The point to note from the quantile analysis is that there is a considerable amount of variation in predicted earnings within subjects. The 90-10 differential in predicted log-wage is reported for each subject in the last column of Table 4. Math, Law, Arts, IT, Economics and Finance are subjects with the largest range, reaching 0.80 to 0.97 log points; i.e. graduates from the top quantile earn almost twice as much as those from the bottom quantile, even after accounting for personal characteristics and academic ability. Even in subjects with less variation, the 90-10 differential reaches 0.60 . This compares with between subject differential which was around 0.25 when excluding medics. So the expected wage differential within subject is considerable larger than between subjects. Note that there is no relationship between the median predicted wage and the within subject range, even after excluding medics who enjoy the highest earnings and one of the lowest variation. Graduates in high variance subjects do not get compensated for the risk. 


\section{Discussion}

As more countries, including the UK are liberalising their market for higher education, we now discuss the implication of the wage differential on the willingness to pay for degrees in different subjects. Under the funding arrangement in place since 2006 in England, institutions can charge up to £3,290 students take an interest free loan to cover tuition and maintenance (up to $£ 5,239$ per year in 2011) ${ }^{11}$. The reimbursement is income contingent at a rate of $9 \%$ for each pound above yearly gross earnings of $£ 15,000$. After 25 years any remaining debt is cancelled. Such a system is progressive especially for women, with $21 \%$ expected to not reimburse their loan fully; the comparable figure for men is $2 \%$ (Dearden et al. (2008)). We use these parameters to simulate a graduate tax.

We do not argue here for the introduction of a graduate tax but only compute it to approximate a range of tuition fees associated with the subject wage differentials previously calculated $^{12}$. Excluding the $£ 11,000$ of the average loan that occurs from living expenses (as in Dearden et al. 2008), the present value of the tax is equivalent to an up-front tuition fee. We ignore any effect on demand that differential fees would create. While previous research has indicated that prospective students have imperfect knowledge of their future stream of income and that it may not influence their subject choice, tuition fee differential would likely make students more aware of the financial implications of their choices.

We first compute the earning profile of graduates from different subjects using pooled data from the Labour Force Survey (1994-2010) and estimate an equation

\footnotetext{
${ }^{11}$ Details on the financing available to students can be found from the Student Loan Company (2010). For students starting their course after September 08, a 5-year "holiday" period has also been introduced which allows graduates to defer any payment for up to 5 years. While all graduates should take this option this is not incorporated in the calculation. An option to repay the loan quicker also exists but is not used in the calculations.

${ }^{12}$ For more details on the benefits and drawbacks of a graduate tax see Garcia-Penalosa and Wälde, (2000) or Chapman (2006).
} 
similar to specification (2) but also including interactions between subject and dummies for age $\mathrm{a}^{13}$. The analysis is done separately by gender to account for differences in the wage profile. Non-working individuals are recoded has having a zero wage. The resulting wage profiles are plotted for a selection of subjects in Figures $3 \mathrm{~A}$ and $3 \mathrm{~B}$ for men and women respectively. For men, up to the age of 50, the profiles are reasonably similar between subjects and thus we make the assumption that subject wage differential are constant over the life time of graduates. Relying on cross sectional data we cannot separate life-cycle effects from cohort effects, so these estimates only provide an approximation of the life cycle that current students may experience. For women, the wage profiles do vary by subjects. This is partly due to changes in the composition of the population of female graduates between cohorts.

As a starting point, we use the wage profiles of management graduates since this a subject which is a popular for both men and women and whose wage profile in the DHLE is similar to physics. Starting from the wage profile of management graduates, a 25 years long graduate tax is equivalent to a tuition fee of £2,190 (allowing for $£ 11,000$ of maintenance expenditure and using a discount rate of $3.5 \%{ }^{14}$. Since the LFS data shows that the subject specific wage differentials are reasonably constant over time, we use our estimated range of premium and report (Table5) the implied tuition fees for graduates from subjects earning $10 \%$ less to $15 \%$ more than business and administration. Based on the wage differentials calculated, the tax present value for different subjects is equivalent to tuition fees in the range from $£ 1,900$ to $£ 5,300$ per year. This compares with the current tuition fees of $£ 3,290$. However, it is important to note the large differences in implied tuition fees by gender. Due to their

\footnotetext{
${ }^{13}$ The LFS defines 19 subjects (not exactly as in the LDHLE). The regression does not control for parental social class. The age dummies are for 5 year band categories

${ }^{14}$ The current Treasury recommended discount rate is 3.5\% (HMT Green Book). We calculate the present value at age 18 , when young people typically start university.
} 
lower participation to the labour market women's wage profile are much lower and flatters than men's. This has a large impact on the total amount that would be collected by a graduate tax. For the average management student, the implied tuition fee for women is only $25 \%$ of the men's, this share is even lower for low earning subjects.

The draft higher education regulations (2010) increases the threshold at which payments are made to $£ 21,000$ and the write off period to 30 years but reduce the interest subsidy for graduates with earning above the $£ 21,000$ threshold. It also lifts the cap on tuition fees to $£ 9,000$ (under wider access conditions). In the second panel, we recalculate the implied tuition fees using these parameters. Apart for top- earners, this reduces the amount of tax collected as the effect of the higher repayment threshold dominates the expansion of the payment period. The implied tuition fee for the average management graduate is thus reduced by $45 \%$. With these parameters, the implied tuition fees are nil for women, up to those with a wage profile $10 \%$ higher than the mean management graduate. For men, the fees range from $£ 3,300$ to $£ 7,100$.

Since most of the variation in wages is within rather than between subjects, we replicate the simulations for graduates at different point of the participation adjusted wage distribution. We assume that a graduate in a given percentile of the earning distribution remains at this percentile throughout his live. This lack of mobility underestimates the lower fee band, especially for women who will experience more variation in their positions in the distribution through getting in and out of the labour force. Under a 25 years graduate tax, the present value of the tax for the median graduate implies fees lower than the current cap, at $£ 2,000$, with fees ranging from 0 to $£ 9,600$. Again there is a large amount of variation by gender. Only for graduates in the top $75^{\text {th }}$ percentile of the distribution ( $90^{\text {th }}$ for women) is the implied fee in the 
range of those recently proposed. Moving to a 30 years repayment system with a higher threshold at which repayments start implies reduced tuition fees.

Those back of the envelope calculations indicate that there is some scope for pricing subjects differently. Similarly, Walker and Zhu (2010) compute large differences in the internal rate of returns by broad subject categories. What these calculations have also indicated is the large gender variation in implied fees. This is due to the lower earning profile for women and their lower participation to the labour market. Since tuition fees cannot be differentiated by gender, an average tuition fees may have a large impact on the gender balance of subjects. Finally, with the parameters used to simulate the tax, only individuals in the top quartile of the earning distribution would generate earnings allowing them to repay the tuition fees to be introduced for 2012.

\section{Conclusions}

We use a cohort of recent graduates to estimate the differences in early labour market attainment by subject of graduation. Even after controlling for a large array of individual characteristics which could be correlated to subject choice, a large dispersion in subject specific mean wages remains (0.26 log points, excluding medical degrees). To put these differences into context, we compute a graduate tax to calculate an implied tuition fee using parameters of the current English loan system. These implied tuition fees range from $£ 1,900$ to $£ 5,300$, but differ largely by gender. Indeed a substantial fraction of graduates especially females, would pay lower fees than currently. This fraction becomes larger under a new set of parameters stemming from a proposed reform of higher education financing which extend the threshold at which payments start and the period of payment. 
The calculations presented provide some metric to put into perspectives subject wage differentials. They do not represent differences in the costs of provision of education or relative demand, nor should they be taken as evidence to advocate a graduate tax, or subject specific fees. Also, we ignore the effect on participation and subject choice that such a fee structure may have. Moreover, under the current financial system of deferred tuition fees, graduates are insured against poor labour market outcomes. Indeed while the reforms aim to foster a market in higher education, this insurance isolates graduates with poor prospective outcomes from the financial consequences of their choices. In fact, those individuals may become indifferent to tuition fees in the knowledge that they will never pay them back fully. Finally, subject specific wage premiums are dwarfed by the differences in wages within subject. Thus under the current funding arrangement in England, it is unclear how much students would react to subject specific tuition fees.

\section{Reference:}

Arcidiacono, P. (2004). Ability sorting and the returns to college major. Journal of Econometrics, 121, 343-375.

Beffy, M., Fougere, D. \& Maurel, A. (2009). Post secondary education: do expected earnings matter? IZA, DP 4127.

Bratti, M. \& Manchini, L. (2003). Differences in Early Occupational Earnings of UK Male Graduates by Degree Subject: Evidence from the 1980-1993 USR, IZA, DP 890.

Bratti, M., Naylor, R. \& Smith, J. (2005). Variations in the Wage Returns to a First Degree: Evidence from the British Cohort Study 1970, IZA, DP 1631

Chapman, B. (2006). Income Contingent Loans for Higher Education: International Reform, in E. Hanushek and F. Welch (eds). Handbook of the Economics of Education, North-Holland, Amsterdam

Chevalier, A. (2010). Does higher education quality matter in the UK. Royal Holloway, Mimeo.

Chevalier, A., Conlon, G., Galindo-Rueda, R. \& McNally, S. (2002). The Returns to Higher Education Teaching. Research Report to the Department for Education and Skills, London: Centre for the Economics of Education, LSE. 
Chevalier, A., Gibbons, S., Thorpe, A., Snell, M., \& Hoskins, S. (2009). Students' academic self-perception, Economics of Education Review, 28, 716-727.

Dearden, L., Fitzimons, E., Goodman, A., \& Kapan, G. 2008. Higher education Funding Reforms in England: The Distributional Effects and the Shifting Balance of Costs, Economic Journal, 118, F100-F125.

DfES (2003). The Future of Higher Education, Department for Education and Skills.

Garcia-Penalosa, C. \& Wälde, K. 2000. Efficiency and Equity Effects of Subsidies to Higher Education, Oxford Economic Papers, 52, 702-722.

James, E., Nabeel, A., Conaty, J., \& To, D. (1989). College quality and future earnings: where should you send your child to college? American Economic Review, 79, 247-252.

Koenker, R. \& Basset, G. (1978). Regression Quantiles, Econometrica, 46, 33-50.

Machin, S. \& Puhani, P. (2006). The contribution of Degree Subject to the Gender Wage Gap for Graduates: A Comparison of Britain, France and Germany, Report to the Anglo-German Foundation.

Naylor R., Smith, J. \& McKnight, A. (2002). The impact of schooling on graduate earnings. Bulletin of Economic Research, 54, special issue, 315-340.

Tipping S., \& Taylor, R. (2007). Destination of Leavers from Higher Education Longitudinal Survey 2002/3 Cohort: Assessment of robustness and fitness for purpose. Higher Education Statistical Agency.

Walker, I., \& Zhu, Y. (2005). The College Wage Premium, Overeducation, and the Expansion of Higher Education in the UK. Scandinavian Journal of Economics, 110. 695-709.

Walker, I. \& Zhu, Y. (2010). Differences by degree: Evidence of the net financial rates of return to undergraduate studies for England and Wales. Economics of Education Review (forthcoming). 
Figure 1: Distribution of annual wages by subject of graduation
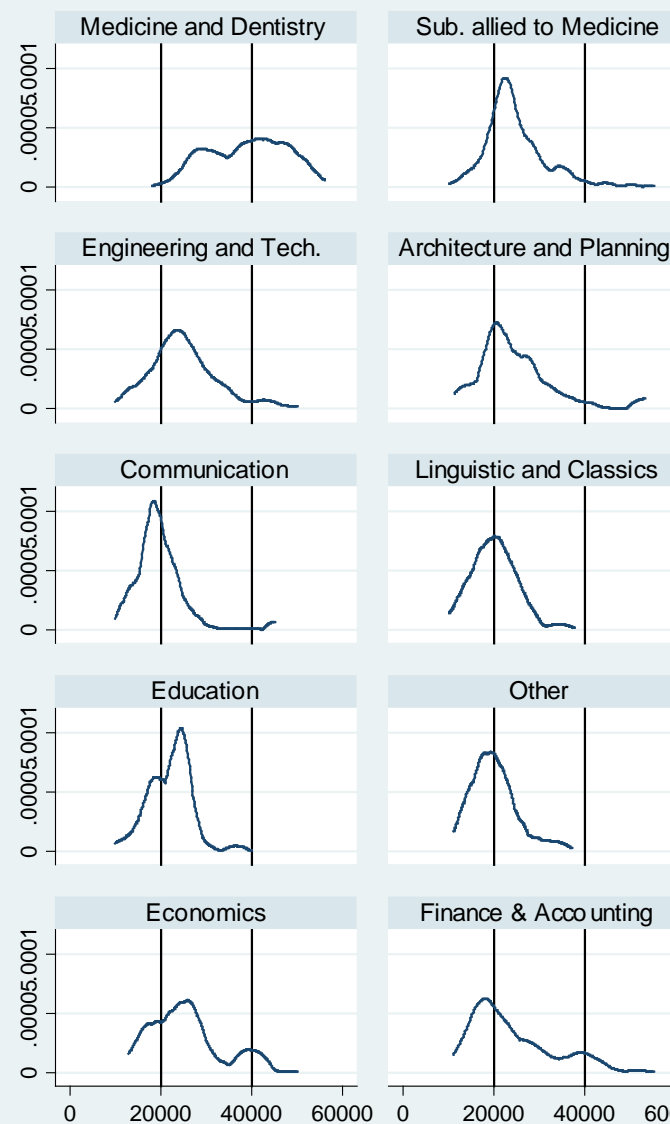

Architecture and Planning

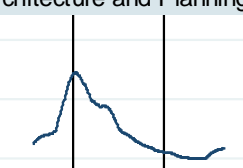

Linguistic and Classics
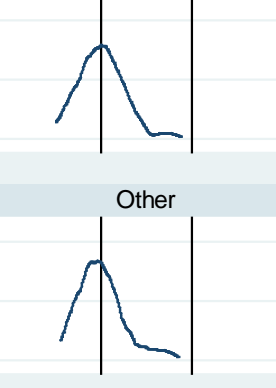

Finance \& Acco unting

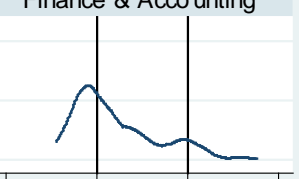

$20000 \quad 40000 \quad 60000$

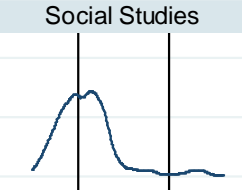

Language and literature

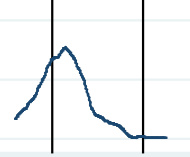

Sport science

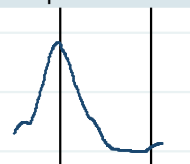

mixed no science

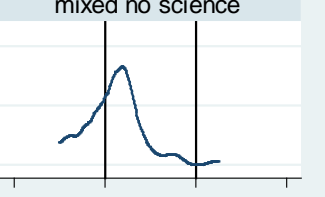

annual wage

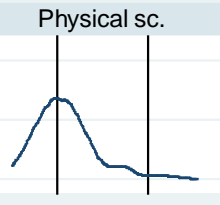

Law

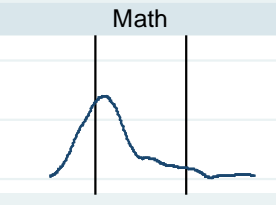

Business and admin

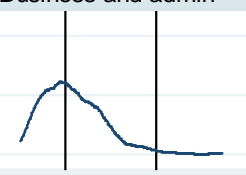

Creative Arts

History and Philosophy
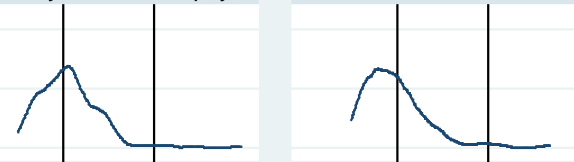

psychology

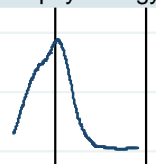

Mixed 45-55 science
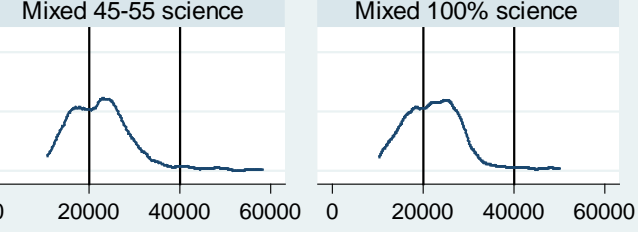

Graphs by refined subject 
Figure 2: Estimated log wages by subject at different quantiles

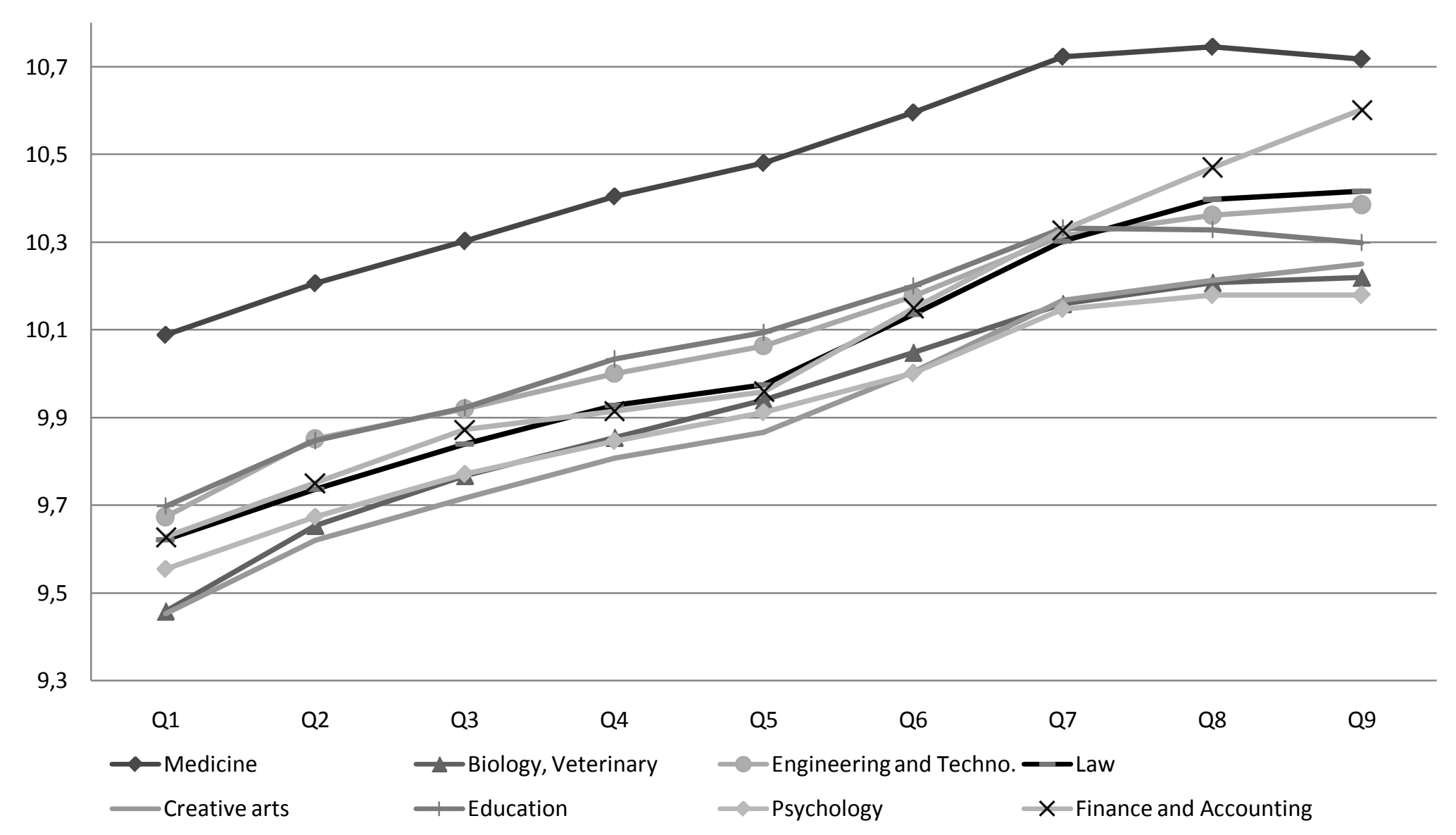

Note: Predicted ln wages based on quantile regressions, see Table 4. The graph only reports a selection of subjects - all subjects were included in the estimation. 
Figure 3A: Estimated life cycle profiles for a subset of subjects - Males

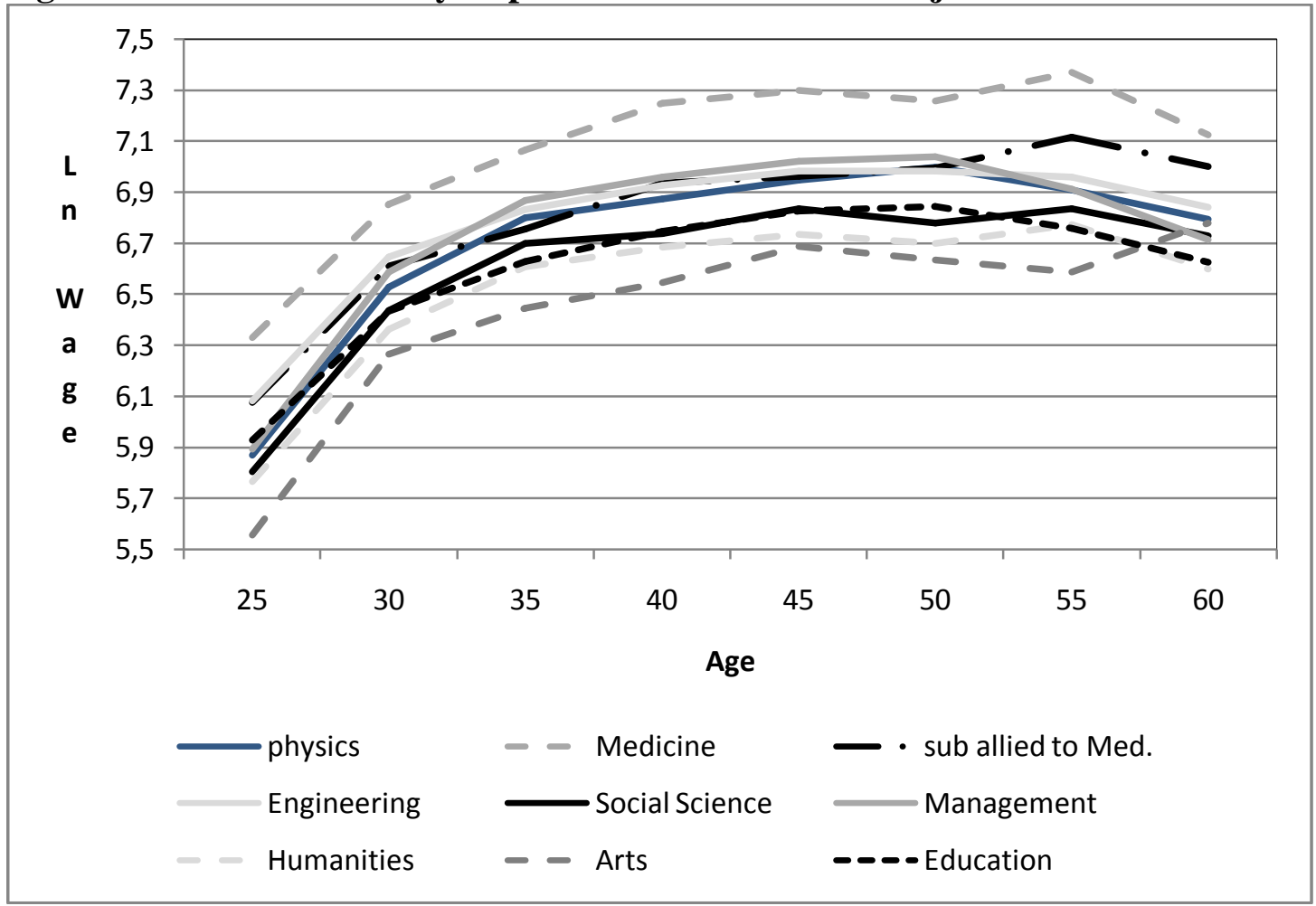

Figure 3B: Estimated life cycle profiles for a subset of subjects - Females

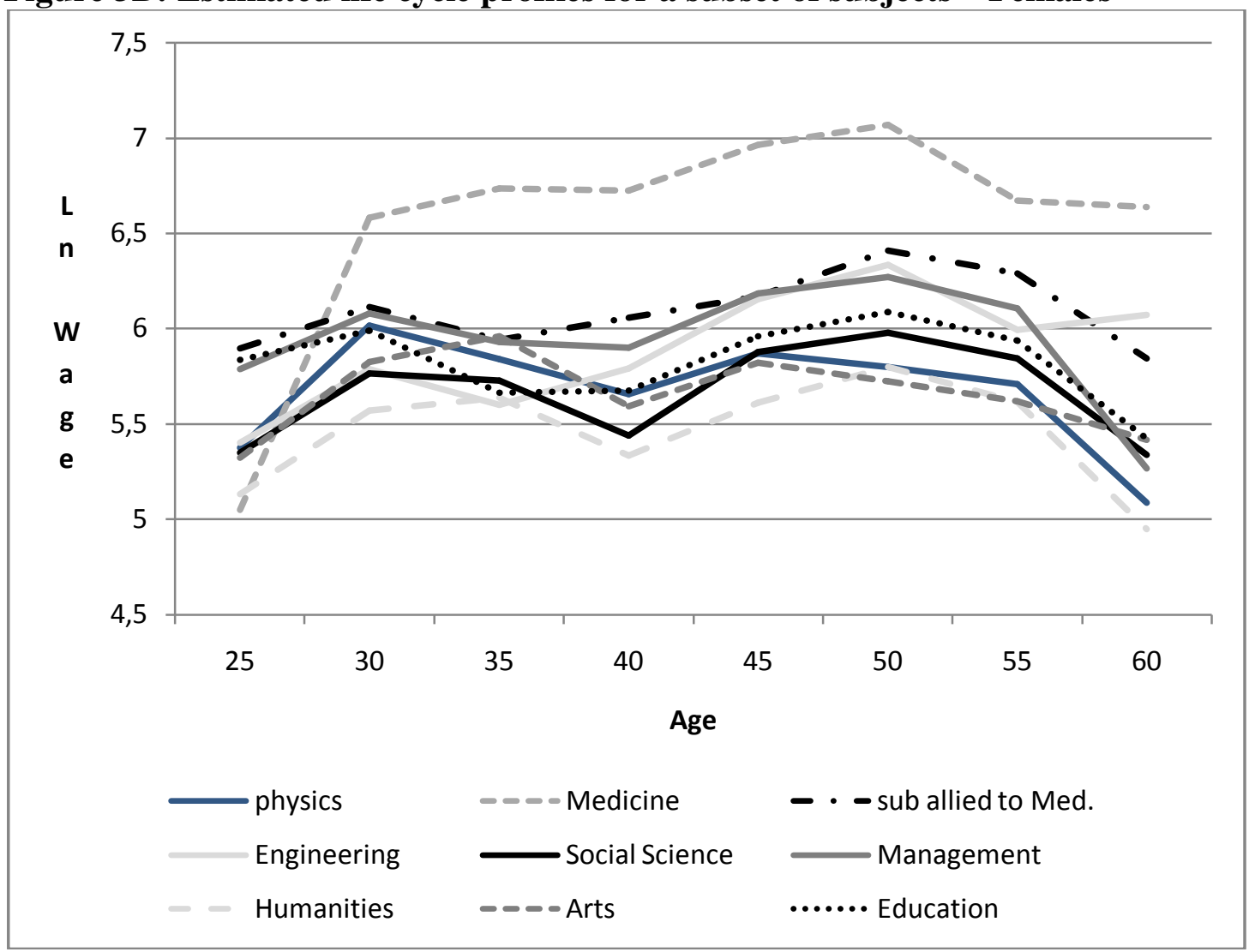

Note: Estimates based on gender specific OLS regression for graduates observed in LFS 1994-2010 controlling for region of residence and year of interview 
Table 1: A-level score (or equivalent) and institution quality by subject of study

\begin{tabular}{|c|c|c|c|c|c|}
\hline Subject & $\begin{array}{l}\text { Mean A- } \\
\text { level score }\end{array}$ & $\begin{array}{l}\text { Mean } \\
\text { Quality } \\
\text { score } \\
\end{array}$ & $\begin{array}{l}\text { Mean } \\
\text { Earnings }\end{array}$ & $\begin{array}{l}\text { Std. } \\
\text { Dev. }\end{array}$ & Obs. \\
\hline Medicine and Dentistry & 28.11 & 2.36 & 38950 & 8632 & 331 \\
\hline Sub. allied to Medicine & 20.31 & -0.09 & 24495 & 6534 & 762 \\
\hline Biology, vet, agriculture & 18.61 & 0.65 & 19993 & 6101 & 325 \\
\hline Physical science & 19.30 & 0.99 & 21364 & 6213 & 281 \\
\hline Mathematics & 24.16 & 1.78 & 24532 & 7755 & 177 \\
\hline Engineering and Tech. & 19.18 & 0.62 & 24602 & 7018 & 486 \\
\hline Architecture and Planning & 16.63 & -0.09 & 23680 & 7068 & 147 \\
\hline Social Studies & 19.36 & 0.36 & 21614 & 6191 & 419 \\
\hline Law & 23.00 & 0.71 & 22880 & 8658 & 309 \\
\hline Business and administration & 16.09 & -0.71 & 20976 & 6543 & 918 \\
\hline Communication & 16.43 & -0.88 & 19876 & 5750 & 161 \\
\hline Linguistic and Classics & 22.13 & 1.14 & 19979 & 5588 & 202 \\
\hline Language and literature & 23.30 & 1.33 & 21711 & 5980 & 128 \\
\hline History and Philosophy & 22.06 & 1.45 & 20517 & 6398 & 226 \\
\hline Creative Arts & 15.53 & -0.61 & 19293 & 6124 & 384 \\
\hline Education & 15.06 & -0.36 & 22699 & 4433 & 253 \\
\hline Other & 17.34 & -0.84 & 20069 & 5684 & 50 \\
\hline Sport science & 17.68 & -0.89 & 20165 & 5333 & 100 \\
\hline Psychology & 20.29 & 0.12 & 19514 & 4649 & 245 \\
\hline IT & 16.56 & -0.43 & 23036 & 7210 & 508 \\
\hline Economics & 24.23 & 1.58 & 25445 & 7832 & 110 \\
\hline Finance \& Accounting & 18.23 & -0.46 & 22782 & 8011 & 173 \\
\hline Mixed no science & 18.15 & -0.16 & 22664 & 5230 & 374 \\
\hline Mixed 45-55 science & 19.62 & 0.13 & 22546 & 6211 & 566 \\
\hline Mixed 100\% science & 21.67 & 1.42 & 22037 & 7191 & 100 \\
\hline Total & 19.50 & 0.26 & 22926 & 7760 & 7735 \\
\hline
\end{tabular}

Note: Source LDLHE 02/03. Sample restricted to individuals with positive value of the score.

The score is obtained by taking the best three A-levels, grades A, B C, D and E are equivalent to 10, 8, 6, 4, 2 points respectively. - means for cells with less than 50 observations are not reported. 
Table 2: OLS Estimates on the effect of subject of degree on annual earnings

\begin{tabular}{|c|c|c|c|c|c|c|c|c|c|c|}
\hline & $(1)$ & $(2)$ & $(3)$ & (4) & $(5)$ & (6) & $(7)$ & $(8)$ & $(9)$ & $(10)$ \\
\hline Medicine & $\begin{array}{r}0.611 \\
{[25.253]}\end{array}$ & $\begin{array}{r}0.613 \\
{[27.134]}\end{array}$ & $\begin{array}{r}0.578 \\
{[24.615]}\end{array}$ & $\begin{array}{c}0.523 \\
{[22.303]}\end{array}$ & $\begin{array}{r}0.508 \\
{[21.627]}\end{array}$ & $\begin{array}{r}0.502 \\
{[21.351]}\end{array}$ & $\begin{array}{r}0.490 \\
{[20.374]}\end{array}$ & $\begin{array}{r}0.490 \\
{[17.681]}\end{array}$ & $\begin{array}{r}0.429 \\
{[13.478]}\end{array}$ & $\begin{array}{r}0.413 \\
{[13.118]}\end{array}$ \\
\hline Subject allied to Medicine & $\begin{array}{r}0.137 \\
{[6.849]}\end{array}$ & $\begin{array}{r}0.14 \\
{[7.478]}\end{array}$ & $\begin{array}{r}0.148 \\
{[7.926]}\end{array}$ & $\begin{array}{c}0.151 \\
{[8.157]}\end{array}$ & $\begin{array}{c}0.151 \\
{[8.244]}\end{array}$ & $\begin{array}{c}0.157 \\
{[8.547]}\end{array}$ & $\begin{array}{c}0.147 \\
{[7.931]}\end{array}$ & $\begin{array}{c}0.153 \\
{[8.409]}\end{array}$ & $\begin{array}{c}0.114 \\
{[6.070]}\end{array}$ & $\begin{array}{r}0.100 \\
{[5.402]}\end{array}$ \\
\hline Biology, Veterinary & $\begin{array}{r}-0.064 \\
{[-3.070]}\end{array}$ & $\begin{array}{c}-0.069 \\
{[3.547]}\end{array}$ & $\begin{array}{c}-0.061 \\
{[3.116]}\end{array}$ & $\begin{array}{c}-0.053 \\
{[2.783]}\end{array}$ & $\begin{array}{l}-0.052 \\
{[2.710]}\end{array}$ & $\begin{array}{c}-0.052 \\
{[2.726]}\end{array}$ & $\begin{array}{c}-0.043 \\
{[2.227]}\end{array}$ & $\begin{array}{c}-0.046 \\
{[2.468]}\end{array}$ & $\begin{array}{c}-0.061 \\
{[3.508]}\end{array}$ & $\begin{array}{l}-0.062 \\
{[3.675]}\end{array}$ \\
\hline Mathematics & $\begin{array}{r}0.125 \\
{[4.917]}\end{array}$ & $\begin{array}{c}0.079 \\
{[3.298]}\end{array}$ & $\begin{array}{c}0.086 \\
{[3.608]}\end{array}$ & $\begin{array}{c}0.07 \\
{[2.981]}\end{array}$ & $\begin{array}{c}0.072 \\
{[3.084]}\end{array}$ & $\begin{array}{c}0.066 \\
{[2.820]}\end{array}$ & $\begin{array}{c}0.067 \\
{[2.908]}\end{array}$ & $\begin{array}{c}0.059 \\
{[2.545]}\end{array}$ & $\begin{array}{c}0.063 \\
{[2.958]}\end{array}$ & $\begin{array}{c}0.062 \\
{[2.945]}\end{array}$ \\
\hline Engineering and Techno. & $\begin{array}{c}0.142 \\
{[7.315]}\end{array}$ & $\begin{array}{c}0.126 \\
{[6.861]}\end{array}$ & $\begin{array}{c}0.107 \\
{[5.839]}\end{array}$ & $\begin{array}{c}0.119 \\
{[6.589]}\end{array}$ & $\begin{array}{c}0.119 \\
{[6.631]}\end{array}$ & $\begin{array}{c}0.118 \\
{[6.586]}\end{array}$ & $\begin{array}{c}0.096 \\
{[5.320]}\end{array}$ & $\begin{array}{c}0.110 \\
{[6.177]}\end{array}$ & $\begin{array}{c}0.077 \\
{[4.616]}\end{array}$ & $\begin{array}{c}0.077 \\
{[4.701]}\end{array}$ \\
\hline Architecture and Planning & $\begin{array}{c}0.113 \\
{[3.925]}\end{array}$ & $\begin{array}{c}0.118 \\
{[4.389]}\end{array}$ & $\begin{array}{l}0.105 \\
{[3.934]}\end{array}$ & $\begin{array}{r}0.130 \\
{[4.945]}\end{array}$ & $\begin{array}{l}0.134 \\
{[5.111]}\end{array}$ & $\begin{array}{l}0.139 \\
{[5.294]}\end{array}$ & $\begin{array}{l}0.131 \\
{[4.981]}\end{array}$ & $\begin{array}{c}0.124 \\
{[4.770]}\end{array}$ & $\begin{array}{c}0.111 \\
{[4.572]}\end{array}$ & $\begin{array}{c}0.092 \\
{[3.853]}\end{array}$ \\
\hline Social Studies & $\begin{array}{c}0.018 \\
{[0.876]}\end{array}$ & $\begin{array}{c}-0.01 \\
{[0.522]}\end{array}$ & $\begin{array}{c}0.004 \\
{[0.191]}\end{array}$ & $\begin{array}{l}0.010 \\
{[0.511]}\end{array}$ & $\begin{array}{l}0.007 \\
{[0.388]}\end{array}$ & $\begin{array}{l}0.008 \\
{[0.434]}\end{array}$ & $\begin{array}{l}0.012 \\
{[0.626]}\end{array}$ & $\begin{array}{c}0.012 \\
{[0.646]}\end{array}$ & $\begin{array}{c}0.027 \\
{[1.590]}\end{array}$ & $\begin{array}{c}0.022 \\
{[1.339]}\end{array}$ \\
\hline Law & $\begin{array}{c}0.091 \\
{[4.038]}\end{array}$ & $\begin{array}{c}0.037 \\
{[1.747]}\end{array}$ & $\begin{array}{r}0.056 \\
{[2.653]}\end{array}$ & $\begin{array}{c}0.043 \\
{[2.092]}\end{array}$ & $\begin{array}{c}0.042 \\
{[2.050]}\end{array}$ & $\begin{array}{c}0.044 \\
{[2.152]}\end{array}$ & $\begin{array}{c}0.039 \\
{[1.891]}\end{array}$ & $\begin{array}{c}0.048 \\
{[2.347]}\end{array}$ & $\begin{array}{c}0.048 \\
{[2.450]}\end{array}$ & $\begin{array}{c}0.031 \\
{[1.591]}\end{array}$ \\
\hline Business and Admin. & $\begin{array}{c}0.000 \\
{[0.006]}\end{array}$ & $\begin{array}{c}-0.023 \\
{[1.392]}\end{array}$ & $\begin{array}{c}-0.011 \\
{[0.681]}\end{array}$ & $\begin{array}{c}0.017 \\
{[1.004]}\end{array}$ & $\begin{array}{c}0.019 \\
{[1.142]}\end{array}$ & $\begin{array}{c}0.026 \\
{[1.609]}\end{array}$ & $\begin{array}{c}0.022 \\
{[1.313]}\end{array}$ & $\begin{array}{c}0.024 \\
{[1.497]}\end{array}$ & $\begin{array}{c}0.020 \\
{[1.347]}\end{array}$ & $\begin{array}{c}0.014 \\
{[0.941]}\end{array}$ \\
\hline Communication & $\begin{array}{c}-0.082 \\
{[2.952]}\end{array}$ & $\begin{array}{c}-0.114 \\
{[4.411]}\end{array}$ & $\begin{array}{c}-0.096 \\
{[3.733]}\end{array}$ & $\begin{array}{l}-0.083 \\
{[3.289]}\end{array}$ & $\begin{array}{l}-0.079 \\
{[3.113]}\end{array}$ & $\begin{array}{c}-0.065 \\
{[2.582]}\end{array}$ & $\begin{array}{c}-0.071 \\
{[2.757]}\end{array}$ & $\begin{array}{c}-0.069 \\
{[2.769]}\end{array}$ & $\begin{array}{c}-0.011 \\
{[0.460]}\end{array}$ & $\begin{array}{l}-0.015 \\
{[0.649]}\end{array}$ \\
\hline Linguistics and Classic & $\begin{array}{l}-0.075 \\
{[3.158]}\end{array}$ & $\begin{array}{c}-0.113 \\
{[5.071]}\end{array}$ & $\begin{array}{c}-0.097 \\
{[4.387]}\end{array}$ & $\begin{array}{c}-0.106 \\
{[4.843]}\end{array}$ & $\begin{array}{l}-0.105 \\
{[4.827]}\end{array}$ & $\begin{array}{c}-0.108 \\
{[4.976]}\end{array}$ & $\begin{array}{c}-0.097 \\
{[4.440]}\end{array}$ & $\begin{array}{c}-0.113 \\
{[5.284]}\end{array}$ & $\begin{array}{c}-0.085 \\
{[4.270]}\end{array}$ & $\begin{array}{l}-0.083 \\
{[4.236]}\end{array}$ \\
\hline Language and literature & $\begin{array}{c}0.052 \\
{[1.936]}\end{array}$ & $\begin{array}{c}-0.016 \\
{[0.656]}\end{array}$ & $\begin{array}{c}-0.025 \\
{[1.011]}\end{array}$ & $\begin{array}{c}-0.044 \\
{[1.785]}\end{array}$ & $\begin{array}{c}-0.047 \\
{[1.925]}\end{array}$ & $\begin{array}{l}-0.053 \\
{[2.161]}\end{array}$ & $\begin{array}{l}-0.055 \\
{[2.276]}\end{array}$ & $\begin{array}{c}-0.041 \\
{[1.689]}\end{array}$ & $\begin{array}{c}-0.029 \\
{[1.281]}\end{array}$ & $\begin{array}{l}-0.030 \\
{[1.360]}\end{array}$ \\
\hline History and Philosophy & $\begin{array}{c}-0.028 \\
{[1.252]}\end{array}$ & $\begin{array}{c}-0.073 \\
{[3.471]}\end{array}$ & $\begin{array}{l}-0.07 \\
{[3.368]}\end{array}$ & $\begin{array}{c}-0.079 \\
{[3.868]}\end{array}$ & $\begin{array}{c}-0.082 \\
{[4.008]}\end{array}$ & $\begin{array}{c}-0.083 \\
{[4.105]}\end{array}$ & $\begin{array}{l}-0.079 \\
{[3.870]}\end{array}$ & $\begin{array}{c}-0.087 \\
{[4.321]}\end{array}$ & $\begin{array}{c}-0.069 \\
{[3.723]}\end{array}$ & $\begin{array}{l}-0.062 \\
{[3.412]}\end{array}$ \\
\hline Creative arts & $\begin{array}{c}-0.113 \\
{[5.758]}\end{array}$ & $\begin{array}{c}-0.137 \\
{[7.465]}\end{array}$ & $\begin{array}{c}-0.12 \\
{[6.593]}\end{array}$ & $\begin{array}{l}-0.093 \\
{[5.153]}\end{array}$ & $\begin{array}{c}-0.092 \\
{[5.083]}\end{array}$ & $\begin{array}{c}-0.081 \\
{[4.461]}\end{array}$ & $\begin{array}{c}-0.091 \\
{[4.829]}\end{array}$ & $\begin{array}{c}-0.086 \\
{[4.773]}\end{array}$ & $\begin{array}{c}-0.044 \\
{[2.578]}\end{array}$ & $\begin{array}{l}-0.039 \\
{[2.319]}\end{array}$ \\
\hline Education & $\begin{array}{c}0.034 \\
{[1.259]}\end{array}$ & $\begin{array}{c}0.038 \\
{[1.508]}\end{array}$ & $\begin{array}{c}0.061 \\
{[2.437]}\end{array}$ & $\begin{array}{l}0.093 \\
{[3.736]}\end{array}$ & $\begin{array}{l}0.098 \\
{[3.979]}\end{array}$ & $\begin{array}{l}0.103 \\
{[4.161]}\end{array}$ & $\begin{array}{c}0.093 \\
{[3.705]}\end{array}$ & $\begin{array}{r}0.1 \\
{[4.096]}\end{array}$ & $\begin{array}{c}0.052 \\
{[2.293]}\end{array}$ & $\begin{array}{c}0.038 \\
{[1.697]}\end{array}$ \\
\hline
\end{tabular}


Other subjects

Sport sciences

Psychology

IT

Economics

Finance and Accounting

Mixed no science

Mixed 50\% science

Mixed 100\% science

Local labour market

Personal characteristics ${ }^{\mathrm{A}}$

A level score

Other background $^{\mathrm{B}}$

University quality

Institution dummy

Degree class

Job characteristics ${ }^{\mathrm{C}}$

Reasons for current job ${ }^{\mathrm{D}}$

$$
\begin{array}{ccc}
-0.072 & -0.029 & -0.022 \\
{[1.733]} & {[0.732]} & {[0.562]} \\
-0.044 & -0.018 & -0.007 \\
{[1.519]} & {[0.652]} & {[0.265]}
\end{array}
$$

$-0.098$

$-0.094$

$-0.066$

[4.092]

[4.165]

[2.913]

$0.038 \quad 0.040$

[2.497] [2.042] [2.110]

$\begin{array}{lll}0.156 & 0.084 & 0.090\end{array}$

[3.252]

0.049

0.055

0.074

[1.768]

[2.008]

0.011

0.002

0.008

[0.463] [0.108] [0.357]

0.034

0.019

0.026

[1.713]

0.037

$1.032]$

[1.431]

[1.170]

[0.360]

[0.297]

$\mathrm{x}$
-0.011
$[0.291]$

.291]

0.020

$0.757]$

$-0.077$

[3.453]

0.060

3.212]

0.079

2.895]

0.071

2.629]

0.016
$0.770]$

$0.770]$
0.027

[1.472]

0.006

[0.197]
0.005

[0.143]

0.022

0.013
$[0.346]$

0.004
$[0.096]$

.096]

$-0.005$

0.009

[0.171]

[1.442]

[0.169]

$-0.054$

1.358]

$-0.080$

[1.073]

$-0.095$

[3.057]

$0.065 \quad 0.070$

$[2.461]$

[3.661]

[4.653]

$\begin{array}{lll}0.067 & 0.066 & 0.037\end{array}$

3.521] [3.781]

$0.070 \quad 0.062$

[3.615]

[3.607]

[2.221]

$0.055 \quad 0.056$

[2.588] [2.293]

0.078

[2.122]

0.082

[2.042]

[2.278] [2.166]

$[3.418][3.076] \quad[3.042] \quad[3.809] \quad[3.461]$

$\begin{array}{lllllll}{[0.702]} & {[1.025]} & {[1.092]} & {[1.034]} & {[0.647]} & {[0.757]}\end{array}$

$\begin{array}{cccccc}0.028 & 0.033 & 0.033 & 0.034 & 0.028 & 0.024\end{array}$

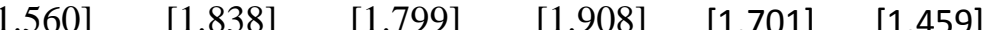

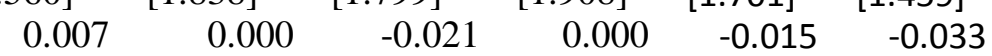

$0.228] \quad[0.017]$

.017]

[0.721]

[0.010]

[0.586]

[1.284]

$\mathrm{R}^{2}$

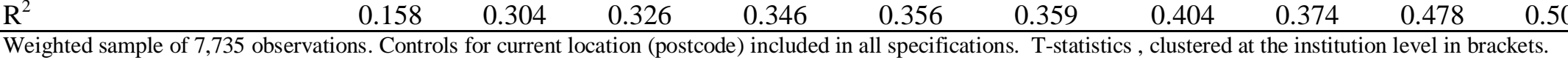

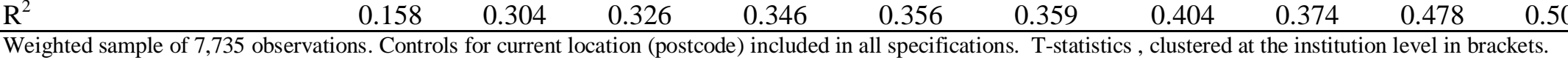

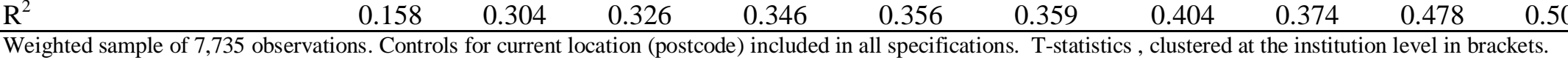

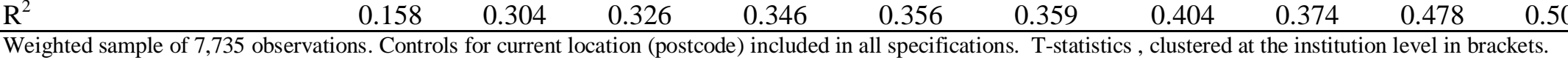

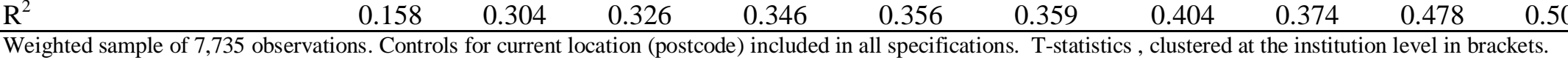

$\begin{array}{cc}\mathrm{X} & \mathrm{X} \\ \mathrm{X} & \mathrm{X} \\ \mathrm{X} & \mathrm{X} \\ \mathrm{X} & \mathrm{X} \\ & \mathrm{X} \\ \mathrm{X} & \end{array}$

$\mathrm{x} \quad \mathrm{X} \quad \mathrm{x}$

$\mathrm{X} \quad \mathrm{X} \quad \mathrm{X}$

$\mathrm{X} \quad \mathrm{X} \quad \mathrm{x}$

$\begin{array}{lll}\mathrm{x} & \mathrm{x} & \mathrm{x} \\ \mathrm{x} & \mathrm{x} & \mathrm{x}\end{array}$ A: Gender, age, ethnicity and parental social class dummies

B:Fee status, accommodation status, disability status, type of school attended

C: Job tenure, permanent contract, employer size dummies, highest qualification dummies, number of jobs since graduating, month of unemployment since graduating

and current occupation (2 digit SOC code)

D:Reasons for accepted current job: career plan, job wanted, best offer, only offer, progress within firm, gain experience, access whether I like it, broaden skills, pay off debt, earn a living 
Table 3: Subject wage differential - by gender

\begin{tabular}{|c|c|c|c|c|c|c|}
\hline & Beta & $\begin{array}{l}\text { lale } \\
\text { Predicted } \\
\text { Ln wage }\end{array}$ & Beta & $\begin{array}{l}\text { Predicted } \\
\text { Ln wage }\end{array}$ & $\begin{array}{r}\text { Coefficient on gender } \\
\text { subject interaction } \\
(6)\end{array}$ & $\begin{array}{r}\text { Coefficient on gender } \\
\text { subject interaction - } \\
\text { full model (10) }\end{array}$ \\
\hline Medicine & $\begin{array}{c}0.507 \\
{[17.512]}\end{array}$ & 10.385 & $\begin{array}{c}0.492 \\
{[12.221]}\end{array}$ & 10.398 & $\begin{array}{c}0.022 \\
{[0.51]}\end{array}$ & $\begin{array}{r}0.002 \\
{[0.048]}\end{array}$ \\
\hline Subject allied to Medicine & $\begin{array}{c}0.147 \\
{[6.713]}\end{array}$ & 10.025 & $\begin{array}{c}0.223 \\
{[5.751]}\end{array}$ & 10.129 & $\begin{array}{c}0.082 \\
{[2.03]}\end{array}$ & $\begin{array}{r}0.074 \\
{[2.024]}\end{array}$ \\
\hline Biology, Veterinary & $\begin{array}{c}-0.071 \\
{[3.082]}\end{array}$ & 9.807 & $\begin{array}{r}-0.04 \\
{[1.128]}\end{array}$ & 9.866 & $\begin{array}{c}0.062 \\
{[1.57]}\end{array}$ & $\begin{array}{r}0.006 \\
{[0.153]}\end{array}$ \\
\hline Physical science & & 9.878 & & 9.906 & $\begin{array}{r}0.027 \\
{[1.00]}\end{array}$ & $\begin{array}{r}0.039 \\
{[1.589]}\end{array}$ \\
\hline Mathematics & $\begin{array}{c}0.048 \\
{[1.590]}\end{array}$ & 9.926 & $\begin{array}{c}0.069 \\
{[1.870]}\end{array}$ & 9.975 & $\begin{array}{c}-0.001 \\
{[0.02]}\end{array}$ & $\begin{array}{r}0.023 \\
{[0.564]}\end{array}$ \\
\hline Engineering and Techno. & $\begin{array}{c}0.069 \\
{[2.164]}\end{array}$ & 9.947 & $\begin{array}{l}0.115 \\
{[4.464]}\end{array}$ & 10.021 & $\begin{array}{c}0.052 \\
{[1.25]}\end{array}$ & $\begin{array}{r}0.001 \\
{[0.022]}\end{array}$ \\
\hline Architecture and Planning & $\begin{array}{c}0.117 \\
{[2.638]}\end{array}$ & 9.995 & $\begin{array}{c}0.119 \\
{[3.216]}\end{array}$ & 10.025 & $\begin{array}{c}-0.012 \\
{[0.21]}\end{array}$ & $\begin{array}{r}-0.015 \\
{[0.283]}\end{array}$ \\
\hline Social Studies & $\begin{array}{c}0.017 \\
{[0.757]}\end{array}$ & 9.895 & $\begin{array}{l}-0.018 \\
{[0.521]}\end{array}$ & 9.888 & $\begin{array}{r}0.007 \\
{[0.17]}\end{array}$ & $\begin{array}{r}0.003 \\
{[0.084]}\end{array}$ \\
\hline Law & $\begin{array}{c}0.003 \\
{[0.143]}\end{array}$ & 9.881 & $\begin{array}{c}0.113 \\
{[2.885]}\end{array}$ & 10.019 & $\begin{array}{c}0.117 \\
{[2.78]}\end{array}$ & $\begin{array}{r}0.084 \\
{[2.245]}\end{array}$ \\
\hline Business and Admin. & $\begin{array}{c}0.016 \\
{[0.773]}\end{array}$ & 9.894 & $\begin{array}{l}0.018 \\
{[0.683]}\end{array}$ & 9.924 & $\begin{array}{c}0.027 \\
{[0.83]}\end{array}$ & $\begin{array}{r}0.013 \\
{[0.460]}\end{array}$ \\
\hline Communication & $\begin{array}{c}-0.029 \\
{[0.961]}\end{array}$ & 9.849 & $\begin{array}{l}-0.142 \\
{[3.211]}\end{array}$ & 9.764 & $\begin{array}{r}-0.078 \\
{[1.56]}\end{array}$ & $\begin{array}{r}-0.075 \\
{[1.674]}\end{array}$ \\
\hline Linguistics and Classic & -0.075 & 9.803 & -0.168 & 9.738 & -0.139 & -0.097 \\
\hline
\end{tabular}




\begin{tabular}{|c|c|c|c|c|c|c|}
\hline \multirow{3}{*}{ Language and literature } & [3.019] & & [3.573] & & [2.91] & [2.245] \\
\hline & -0.055 & 9.823 & -0.012 & 9.894 & 0.041 & 0.029 \\
\hline & [1.979] & & {$[0.216]$} & & {$[0.75]$} & {$[0.600]$} \\
\hline \multirow[t]{2}{*}{ History and Philosophy } & -0.036 & 9.842 & -0.143 & 9.763 & -0.090 & -0.061 \\
\hline & [1.375] & & {$[4.243]$} & & {$[2.24]$} & [1.688] \\
\hline \multirow[t]{2}{*}{ Creative arts } & -0.085 & 9.793 & -0.098 & 9.808 & 0.026 & 0.056 \\
\hline & [3.693] & & [3.142] & & {$[0.74]$} & [1.717] \\
\hline \multirow[t]{2}{*}{ Education } & 0.158 & 10.036 & -0.088 & 9.818 & -0.215 & -0.157 \\
\hline & {$[5.826]$} & & {$[1.502]$} & & {$[3.76]$} & [3.035] \\
\hline \multirow[t]{2}{*}{ Other subjects } & 0.014 & 9.892 & 0.043 & 9.949 & 0.036 & 0 \\
\hline & [0.290] & & [0.631] & & {$[0.48]$} & [0.004] \\
\hline \multirow[t]{2}{*}{ Sport sciences } & 0.086 & 9.964 & -0.006 & 9.9 & -0.059 & 0.007 \\
\hline & [2.451] & & {$[0.133]$} & & [1.12] & [0.147] \\
\hline \multirow[t]{2}{*}{ Psychology } & -0.069 & 9.809 & -0.062 & 9.844 & 0.036 & 0.024 \\
\hline & [2.809] & & [1.101] & & {$[0.67]$} & [0.493] \\
\hline \multirow[t]{2}{*}{ IT } & 0.017 & 9.895 & 0.099 & 10.005 & 0.087 & 0.076 \\
\hline & {$[0.612]$} & & [3.594] & & {$[2.26]$} & [2.193] \\
\hline \multirow[t]{2}{*}{ Economics } & -0.053 & 9.825 & 0.116 & 10.022 & 0.167 & 0.116 \\
\hline & [1.362] & & {$[2.868]$} & & {$[3.05]$} & [2.343] \\
\hline \multirow[t]{2}{*}{ Finance and Accounting } & 0.112 & 9.99 & 0.087 & 9.993 & -0.016 & -0.033 \\
\hline & {$[2.950]$} & & {$[2.146]$} & & {$[0.3]$} & [0.685] \\
\hline \multirow[t]{2}{*}{ Mixed no science } & 0.082 & 9.96 & -0.152 & 9.754 & -0.206 & -0.16 \\
\hline & [3.342] & & [3.729] & & {$[4.68]$} & [4.048] \\
\hline \multirow[t]{2}{*}{ Mixed 50\% science } & 0.081 & 9.959 & -0.034 & 9.872 & -0.094 & -0.085 \\
\hline & [3.558] & & {$[1.095]$} & & [2.59] & [2.611] \\
\hline \multirow[t]{2}{*}{ Mixed 100\% science } & 0.03 & 9.908 & -0.016 & 9.89 & 0.015 & 0.044 \\
\hline & [0.787] & & [0.215] & & {$[0.26]$} & [0.863] \\
\hline
\end{tabular}


Table 4: Subject wage differential: Quantile regression

\begin{tabular}{|c|c|c|c|c|c|c|c|c|c|c|}
\hline & Q1 & Q2 & Q3 & Q4 & Q5 & Q6 & Q7 & $\mathrm{Q} 8$ & Q9 & $\begin{array}{r}\text { Expected } \\
\text { Q9-Q1 } \\
\text { wages }\end{array}$ \\
\hline \multirow[t]{2}{*}{ Medicine } & 0.531 & 0.505 & 0.524 & 0.508 & 0.554 & 0.52 & 0.485 & 0.498 & 0.395 & 0.657 \\
\hline & [0.009] & [0.007] & [0.019] & {$[0.010]$} & [0.013] & [0.013] & {$[0.007]$} & [0.018] & {$[0.021]$} & \\
\hline \multirow[t]{2}{*}{ Subject allied to Medicine } & 0.162 & 0.203 & 0.208 & 0.169 & 0.172 & 0.137 & 0.096 & 0.115 & 0.079 & 0.681 \\
\hline & {$[0.008]$} & [0.006] & {$[0.016]$} & {$[0.008]$} & [0.011] & [0.011] & {$[0.006]$} & {$[0.016]$} & [0.018] & \\
\hline \multirow[t]{2}{*}{ Biology, Veterinary } & -0.1 & -0.047 & -0.01 & -0.042 & 0.013 & -0.027 & -0.078 & -0.041 & -0.102 & 0.762 \\
\hline & {$[0.010]$} & [0.007] & {$[0.019]$} & {$[0.010]$} & [0.013] & [0.014] & {$[0.007]$} & {$[0.020]$} & {$[0.023]$} & \\
\hline Physics (base category) & & & & & & & & & & 0.764 \\
\hline \multirow[t]{2}{*}{ Mathematics } & 0.137 & 0.077 & 0.106 & 0.041 & 0.067 & 0.04 & 0.015 & 0.103 & 0.174 & 0.801 \\
\hline & [0.012] & [0.009] & [0.024] & {$[0.012]$} & {$[0.016]$} & {$[0.016]$} & {$[0.008]$} & {$[0.023]$} & {$[0.026]$} & \\
\hline \multirow[t]{2}{*}{ Engineering and Techno. } & 0.115 & 0.15 & 0.142 & 0.104 & 0.136 & 0.101 & 0.077 & 0.113 & 0.063 & 0.712 \\
\hline & [0.009] & [0.007] & [0.018] & {$[0.010]$} & [0.012] & [0.013] & {$[0.006]$} & [0.018] & {$[0.020]$} & \\
\hline \multirow[t]{2}{*}{ Architecture and Planning } & 0.111 & 0.131 & 0.139 & 0.073 & 0.092 & 0.102 & 0.085 & 0.164 & 0.137 & 0.79 \\
\hline & {$[0.013]$} & [0.010] & {$[0.026]$} & [0.014] & [0.017] & [0.018] & [0.009] & {$[0.026]$} & {$[0.029]$} & \\
\hline \multirow[t]{2}{*}{ Social Studies } & 0.036 & 0.035 & 0.067 & 0.021 & 0.05 & 0.019 & -0.022 & 0.001 & -0.019 & 0.709 \\
\hline & {$[0.009]$} & [0.007] & [0.019] & {$[0.010]$} & [0.013] & [0.013] & {$[0.007]$} & [0.019] & {$[0.022]$} & \\
\hline \multirow[t]{2}{*}{ Law } & 0.063 & 0.036 & 0.062 & 0.032 & 0.048 & 0.059 & 0.065 & 0.149 & 0.094 & 0.795 \\
\hline & [0.009] & [0.007] & [0.020] & [0.011] & [0.014] & [0.014] & {$[0.007]$} & [0.020] & [0.024] & \\
\hline \multirow[t]{2}{*}{ Business and Admin. } & 0.012 & 0.014 & 0.042 & -0.001 & 0.049 & 0.045 & 0.021 & 0.042 & 0.038 & 0.79 \\
\hline & [0.009] & [0.006] & [0.016] & {$[0.009]$} & [0.011] & [0.012] & {$[0.006]$} & [0.017] & [0.019] & \\
\hline \multirow[t]{2}{*}{ Communication } & -0.057 & 0.055 & 0.059 & 0.004 & 0.002 & -0.016 & -0.086 & -0.095 & -0.175 & 0.652 \\
\hline & {$[0.009]$} & [0.009] & [0.024] & {$[0.013]$} & [0.017] & [0.017] & [0.009] & {$[0.022]$} & [0.024] & \\
\hline \multirow[t]{2}{*}{ Linguistics and Classic } & -0.026 & -0.021 & -0.01 & -0.074 & -0.059 & -0.056 & -0.091 & -0.075 & -0.188 & 0.641 \\
\hline & {$[0.012]$} & [0.008] & [0.022] & {$[0.012]$} & [0.015] & {$[0.016]$} & {$[0.008]$} & {$[0.021]$} & {$[0.020]$} & \\
\hline \multirow[t]{2}{*}{ Language and literature } & -0.021 & 0.01 & 0.02 & 0.001 & 0.043 & 0.024 & -0.008 & -0.029 & -0.102 & 0.693 \\
\hline & [0.013] & [0.009] & {$[0.025]$} & {$[0.014]$} & {$[0.018]$} & [0.018] & [0.009] & [0.024] & {$[0.027]$} & \\
\hline
\end{tabular}




\begin{tabular}{lrrrrrrrrrr} 
History and Philosophy & -0.093 & -0.056 & -0.013 & -0.042 & -0.037 & -0.082 & -0.097 & -0.037 & -0.07 & 0.787 \\
& {$[0.010]$} & {$[0.008]$} & {$[0.020]$} & {$[0.011]$} & {$[0.014]$} & {$[0.015]$} & {$[0.007]$} & {$[0.021]$} & {$[0.025]$} & \\
Creative arts & -0.105 & -0.081 & -0.061 & -0.088 & -0.061 & -0.072 & -0.071 & -0.035 & -0.072 & 0.797 \\
& {$[0.010]$} & {$[0.007]$} & {$[0.018]$} & {$[0.010]$} & {$[0.013]$} & {$[0.013]$} & {$[0.007]$} & {$[0.019]$} & {$[0.021]$} & \\
Education & 0.14 & 0.146 & 0.145 & 0.137 & 0.167 & 0.124 & 0.094 & 0.08 & -0.023 & 0.634 \\
& {$[0.010]$} & {$[0.008]$} & {$[0.023]$} & {$[0.012]$} & {$[0.015]$} & {$[0.015]$} & {$[0.007]$} & {$[0.020]$} & {$[0.021]$} & \\
Other subjects & 0.025 & -0.013 & 0.046 & 0.048 & 0.047 & 0.015 & -0.081 & -0.077 & -0.191 & 0.588 \\
& {$[0.012]$} & {$[0.013]$} & {$[0.033]$} & {$[0.019]$} & {$[0.024]$} & {$[0.024]$} & {$[0.012]$} & {$[0.031]$} & {$[0.033]$} & \\
Sport sciences & -0.042 & 0.108 & 0.057 & 0.029 & 0.067 & 0.007 & -0.044 & 0.002 & -0.079 & 0.734 \\
& {$[0.013]$} & {$[0.010]$} & {$[0.027]$} & {$[0.015]$} & {$[0.019]$} & {$[0.020]$} & {$[0.009]$} & {$[0.028]$} & {$[0.033]$} & \\
Psychology & -0.003 & -0.027 & -0.006 & -0.05 & -0.015 & -0.075 & -0.091 & -0.069 & -0.143 & 0.624 \\
& {$[0.010]$} & {$[0.008]$} & {$[0.021]$} & {$[0.011]$} & {$[0.014]$} & {$[0.015]$} & {$[0.007]$} & {$[0.021]$} & {$[0.023]$} & \\
IT & 0.014 & 0.032 & 0.064 & 0.074 & 0.074 & 0.08 & 0.024 & 0.055 & 0.066 & 0.816 \\
& {$[0.009]$} & {$[0.007]$} & {$[0.018]$} & {$[0.010]$} & {$[0.013]$} & {$[0.013]$} & {$[0.006]$} & {$[0.018]$} & {$[0.021]$} & \\
Economics & 0.102 & 0.093 & 0.159 & 0.075 & 0.145 & 0.089 & 0.025 & 0.131 & 0.132 & 0.794 \\
& {$[0.012]$} & {$[0.010]$} & {$[0.027]$} & {$[0.014]$} & {$[0.019]$} & {$[0.019]$} & {$[0.009]$} & {$[0.029]$} & {$[0.022]$} & \\
Finance and Accounting & 0.07 & 0.05 & 0.095 & 0.019 & 0.032 & 0.073 & 0.09 & 0.222 & 0.28 & 0.974 \\
& {$[0.009]$} & {$[0.009]$} & {$[0.025]$} & {$[0.013]$} & {$[0.017]$} & {$[0.017]$} & {$[0.009]$} & {$[0.026]$} & {$[0.032]$} & \\
Mixed no science & -0.074 & 0.013 & 0.108 & 0.083 & 0.1 & 0.07 & 0.028 & 0.025 & -0.032 & 0.806 \\
& {$[0.011]$} & {$[0.008]$} & {$[0.020]$} & {$[0.010]$} & {$[0.013]$} & {$[0.013]$} & {$[0.007]$} & {$[0.018]$} & {$[0.021]$} & \\
Mixed 50\% science & 0.001 & 0.013 & 0.07 & 0.052 & 0.094 & 0.098 & 0.067 & 0.09 & 0.01 & 0.779 \\
Mixed 100\% science & {$[0.010]$} & {$[0.007]$} & {$[0.018]$} & {$[0.010]$} & {$[0.012]$} & {$[0.013]$} & {$[0.006]$} & {$[0.018]$} & {$[0.021]$} & \\
& 0.022 & 0.039 & 0.071 & 0.044 & 0.065 & 0.015 & 0.015 & 0.007 & -0.147 & 0.675 \\
& {$[0.014]$} & {$[0.010]$} & {$[0.028]$} & {$[0.014]$} & {$[0.019]$} & {$[0.019]$} & {$[0.009]$} & {$[0.023]$} & {$[0.024]$} & \\
\hline
\end{tabular}

The analysis is conducted on the weighted sample of 7,735 observations and controls for age, gender, ethnicity, disability status, A-level score, parental social class, type of school, fee status, class of degree and institution quality. Standard errors reported in brackets. 
Table 5: Graduate tax and implicit tuition fees

\begin{tabular}{|c|c|c|c|}
\hline & \multicolumn{3}{|c|}{ Implied annual tuition fee } \\
\hline $\begin{array}{l}\text { Parameters: } \\
25 \text { years } \\
9 \% \text { over } £ 15,000\end{array}$ & Men & Women & All \\
\hline Management graduate & 4,800 & 1,200 & 3,300 \\
\hline $\begin{array}{l}\text { Graduate earning } 10 \% \\
\text { less through out }\end{array}$ & 3,300 & 100 & 1,900 \\
\hline $\begin{array}{l}\text { Graduate earning 5\% } \\
\text { less through out }\end{array}$ & 4,100 & 600 & 2,600 \\
\hline $\begin{array}{l}\text { Graduate earning 5\% } \\
\text { more through out }\end{array}$ & 5,600 & 1,800 & 3,900 \\
\hline $\begin{array}{l}\text { Graduate earning } 10 \% \\
\text { more through out }\end{array}$ & 6,300 & 2,300 & 4,600 \\
\hline $\begin{array}{l}\text { Graduate earning 15\% } \\
\text { more through out }\end{array}$ & 7,100 & 2,900 & 5,300 \\
\hline 10th earning percentile & 0 & 0 & 0 \\
\hline $25^{\text {th }}$ earning percentile & 600 & 0 & 0 \\
\hline Median graduate & 2,300 & 1,400 & 2,000 \\
\hline $75^{\text {th }}$ earning percentile & 6,900 & 3,400 & 5,300 \\
\hline $90^{\text {th }}$ earning percentile & 11,900 & 6,700 & 9,600 \\
\hline
\end{tabular}

30 years

9\% over $£ 21,000$

\begin{tabular}{|c|c|c|c|}
\hline Management graduate & 3,500 & 0 & 1,800 \\
\hline $\begin{array}{l}\text { Graduate earning } 10 \% \text { less } \\
\text { through out }\end{array}$ & 2,000 & 0 & 400 \\
\hline $\begin{array}{l}\text { Graduate earning 5\% less } \\
\text { through out }\end{array}$ & 2,700 & 0 & 1,100 \\
\hline $\begin{array}{l}\text { Graduate earning 5\% more } \\
\text { through out }\end{array}$ & 4,300 & 0 & 2,600 \\
\hline $\begin{array}{l}\text { Graduate earning } 10 \% \text { more } \\
\text { through out }\end{array}$ & 5,200 & 600 & 3,300 \\
\hline $\begin{array}{l}\text { Graduate earning } 15 \% \text { more } \\
\text { through out }\end{array}$ & 6,000 & 1,200 & 4,000 \\
\hline 10th earning percentile & 0 & 0 & 0 \\
\hline 25th earning percentile & 0 & 0 & 0 \\
\hline Median graduate & 500 & 0 & 200 \\
\hline 75th earning percentile & 5,600 & 1,500 & 3,800 \\
\hline 90th earning percentile & 11,600 & 5,300 & 8,900 \\
\hline
\end{tabular}

Note: Calculations based on the earning profile of graduates in the LFS (1994-2010). The profile is based on the average earnings in 5 years age group, and assuming linear growth over each 5 years period. The graduate tax is paid on growth income above $£ 15,000$ at a rate of $9 \%$ as currently set up by the Student Loan Company. Implicit fees are calculated as the present value of total graduate tax over the payment period minus $£ 11,000$ (which represents the part of a loan due to maintenance, on average) divided by the typical length of a degree. The flow of tax payment is discounted at the HM treasury recommended discount rate of $3.5 \%$ back to age 18 when students make their decision to enter higher education. 


\section{Appendix:}

\section{Table A1: Sample Selection:}

\begin{tabular}{ll}
\hline $\begin{array}{l}\text { Selection criteria }- \text { applied } \\
\text { incrementally }\end{array}$ & Number of observations \\
\hline \hline Original sample & 19,979 \\
First degree only & 11,866 \\
Age on graduation [18,25] & 9,850 \\
Not special entry student & 9,738 \\
Employed FT or PT & 9,296 \\
With valid wages & 8,239 \\
Working full time & 7,735 \\
\hline
\end{tabular}


Table A2: Comparing HESA and LDLHE populations

\begin{tabular}{|c|c|c|c|c|}
\hline \multirow[b]{2}{*}{ Subject of study } & \multicolumn{2}{|c|}{ HESA 2002/03 } & \multirow{2}{*}{$\begin{array}{l}\text { LDLHE } \\
\text { Freq in \%. }\end{array}$} & \multirow{2}{*}{$\begin{array}{l}\text { LDLHE - } \\
\text { valid wage } \\
\text { Freq in \%. }\end{array}$} \\
\hline & Freq. & Percent & & \\
\hline Medicine and Dentistry & 7,475 & 1.81 & 3.00 & 3.06 \\
\hline Sub. allied to Medicine & 42,956 & 10.41 & 6.59 & 6.33 \\
\hline Biology, vet, agriculture & 16,886 & 4.09 & 4.91 & 5.16 \\
\hline Physical science & 15,069 & 3.65 & 4.63 & 4.88 \\
\hline Mathematics & 5,919 & 1.43 & 2.43 & 2,58 \\
\hline Engineering and Tech. & 24,094 & 5.84 & 6.81 & 7.18 \\
\hline Architecture and Planning & 9,082 & 2.20 & 1.83 & 1.84 \\
\hline Social Studies & 25,322 & 6.14 & 5.70 & 5.66 \\
\hline Law & 16,600 & 4.02 & 3.92 & 3.93 \\
\hline Business and administration & 50,979 & 12.36 & 11.84 & 11.93 \\
\hline Communication & 8,781 & 2.13 & 2.18 & 2.05 \\
\hline Linguistic and Classics & 11,310 & 2.74 & 3.40 & 3.25 \\
\hline Language and literature & 6,590 & 1.60 & 2.30 & 2.24 \\
\hline History and Philosophy & 13,787 & 3.34 & 4.15 & 4.06 \\
\hline Creative Arts & 30,196 & 7.32 & 7.71 & 6.95 \\
\hline Education & 37,824 & 9.17 & 2.16 & 2.17 \\
\hline Other & 14,034 & 3.40 & 0.70 & 0.74 \\
\hline Sport science & 3,462 & 0.84 & 1.62 & 1.82 \\
\hline Psychology & 10,320 & 2.50 & 3.23 & 3.13 \\
\hline IT & 23,109 & 5.60 & 6.26 & 6.24 \\
\hline Economics & 5,285 & 1.28 & 1.64 & 1.65 \\
\hline Finance \& Accounting & 5,731 & 1.39 & 1.76 & 1.75 \\
\hline Mixed no science & 8,260 & 2.00 & 3.62 & 3.68 \\
\hline Mixed 45-55 science & 15,420 & 3.74 & 6.27 & 6.30 \\
\hline Mixed 100\% science & 4,088 & 0.99 & 1.35 & 1.43 \\
\hline Total & 412,79 & 100.00 & 9,296 & 7.735 \\
\hline
\end{tabular}

Note: HESA 2002/03 is the sample of eligible DLHE students only.

9,296 is the sample of first degree holder, aged $[18,25]$ without special entry and currently working full-time or part-time.

7.735 is the sample of full-time respondent with valid wage information. 